УДК: 72.035 .1

ББК: 85.113

A43

DOI: $10.18688 / \mathrm{aa} 200-1-11$

M. Sokolova

\title{
National Heritage and Style in Late Victorian Country House Architecture
}

The later years of Queen Victoria's reign saw a marked change in the country's economic and public life. If the preceding decades, known as the High Victorian age, saw the peak of the empire's development, in the 1880s the economic prosperity declined and the country went through a number of crises. That could not but impale the idea of a great national past which inspired certain architectural prototypes borrowed from what was seen as the golden age of the empire.

The new social tendencies were reflected vividly in the work of Ph. Webb. That architect was a friend of W. Morris and his circle where he borrowed aesthetic and social ideas. His biography was far from smooth though. His creative independence, his refusal to please the whims of bad taste cost him clients. His work might have been slowed down due to such conflicts.

$\mathrm{Ph}$. Webb was the first architect who refused to follow just one style. "That Messrs Salvin and Wyatt are 'unable to discover what actual style or period of architecture' I have used, I take to be a sincere compliment", - declared the architect [2, p. 160]. He also used to say, "I never begin to be satisfied until my work looks commonplace" [1, p. 143]. Similar to followers of the vernacular style, he turned to the local building traditions. But, unlike them he never was picturesque in the rural way. On the contrary, like A. W.N. Pugin, he avoided any artificial falsehood, but rather followed the functional aims with priority to comfort.

That certainly led to conflicts with clients, M. Girouard point out that "Webb...was never a complaisant employee" [4, p. 381]. Such a trend in rural architecture made it unclear which social class the owners belonged to. There was a distinct discord between the democratic ideas of the architect and his rich clients. The modest Smeaton Manor in Yorkshire (1875-1878) was rather and exception to the rule, while Standen built for a popular lawyer in Sussex (18911994) was of an impressive size, and Clouds in Wiltshire (1879-1891) for the younger son of Lord Leconfield was of a grand size.

It is obvious that the solid farmers' houses admired by the architect could not be taken as models for imitation. Clouds were to look like an old aristocratic nest, and an old Elizabethan manor was the most acceptable pattern. Yet, unlike his predecessors, the architect revived that image in general, not in details. The proportions, the silhouette with its gabled roofs and turrets of various configurations bring that epoch to the mind. But, there are no Elizabethan windows on the façade. Using a typical sash window of Queen Anne epoch, the architect puts it in an unusual context: the niches give the impression of an order arcade; also a Palladian window is used. 
The architect was probably freer in his work at Standen's project, since the client was not bent on creating an aristocratic residence. He found a smart solution for organizing the architectural masses of that large house. He proceeded from the idea of a rich framer's complex of buildings grouped together. Such solutions were not rare at that time. Webb's socialist ideas prompted him to choose such a democratic model, and unlike his colleagues to give up a complicated plan. He used the classical composition grouping services at 90 grades round the kitchen yard. The central block was simply planned along perpendicular axes.

From the central entrance hall with a staircase, a corridor leads through to a drawing room. That corridor is like the old English double pile house where it is parallel to the façade and splitting the space into two, billiard and study to one side, and dining, sitting rooms, and the winter garden on the other. The façade is all in one line, protruding parts are minimal, and the rooms have simple shapes.

It is of interest that as an architect Webb chooses here a plan different from the one used in the same county by his contemporary R.N. Shaw, who always placed the house on the top of the local relief. The romantic image of a house on top of a rock surrounded by woods is found in nearly all his works. Webb, though, chose a different way. At first glance, he seems to deromanticize the image, but actually he poeticizes and idealizes every-day life. A house placed in a dale amid a garden and services gives no impression of a landlord's home, but the centre of a flourishing farm.

A scheme well-tried in Victorian architecture was used in Clouds: a service block was linked to the main building at right angle. But, the traditional solution was re-considered in terms of special composition. At the height of the Victorian epoch, the service block was much lower, and since it occupied about 70 percent of the house, it proved to be very lengthy. Here the services are numerous, but placed compactly, grouped around the kitchen yard. The linking element was the high right-angled tower at the corner of the building. Thanks to that, the whole composition did not fall apart, which is obvious if you look at the house from the south-west angle.

Generally. Webb built his composition in such a way that it fell into some autonomous façade views. Thus, from the side of the main façade placed in the depth of spacious yard, the house looks like a typical abode in Queen Anne's style - built of bricks with white stone decorations characteristic long sash windows and a high attic roof. Some services concealed partly the angle tower making it less massive and heavy.

That tower looks quite different from outside. The architect used the difference of height. If a house stands on a hill, its size is well-seen, so that a modest tower may dominate the place and gain a solo position in the ensemble of the Victorian house.

However, that is not the end to variety in façade presentation. The most original is the southern façade with its combination of materials: local stone for the foundation, tiles for the first floor, bricks for lintels, white painted window frames, and gables over each window. Tiles have been already used by Webb in his early houses, as S. Muthesius marks "plain tiles...were used...by the Domestic Revivalists like Philip Webb from the 1860s onwards" [6, p. 222]. The most logical principle is in contrasting different heights: the dominant height is the tower above the attic over the principal roof of the block: five gables protruding over the main rooms of the house - the dining and drawing rooms. The adjacent winter garden with large windows is the final touch of the composition. 
Note, though, that Webb's complex solutions were essentially different from those of his predecessors. He was not after a picturesque impression on the public. The variety of his composition is not to show the growth of property over ages, but to point out the main functional zones.

From the stylistic point of view the architects is not after any historical style in its purity. "For architects like Philip Webb and George Devey (1820-1886), the Vernacular was not just a stylistic alternative to Gothic or Classical, but a complete way of designing" [3, pp. 25-26]. He uses willingly elements of epochs and styles combining them unexpectedly. As a result, his work doesn't look eclectic, for he places the original elements in unexpected context.

The work of this architect shows to us the characteristic tendency of the Late Victorian architecture. As H.-R. Hitchcock wrote in regard to Webb's impact on the architecture of the period: "Shaw...shares responsibility for the effectiveness of the mutation away from the High Victorian with... Nesfield, Webb, Godwin, and J.J. Stevenson" [5, p. 291]. The problem of style began to lose its actuality. The style of the 1870-1880s differed from the preceding period in losing any reference to the Middle Ages or any other stylistic tendency. Not by chance, that period is referred to as "Old English" without mention of specifying any historical period. The style is no longer in favor of any ideology, but more pragmatic: the architect uses any style suitable for a practical aim. He leaves it to be chosen by the client without any link to the context of the local buildings.

\section{References}

1. Aslet C. The Last Country Houses. New Haven; London, Yale University Press Publ., 1982. 344 p.

2. Aslet C.; Powers A. English House. Harmondsworth, Penguin Books Publ., 1986. 312 p.

3. Dixon R.; Muthesius S. Victorian Architecture. London, Thames and Hudson Publ., 1978. 288 p.

4. Girouard M. Victorian Country House. New Haven; London, Yale University Press Publ., 1985. 467 p.

5. Hitchcock H.R. Architecture: Nineteenth and Twentieth Centuries. Harmondsworth, Penguin Books Publ., 1982. 688 p.

6. Muthesius S. English Terraced House. New Haven; London, Yale University Press Publ., 1982. 278 p.

Title. National Heritage and Style in Late Victorian Country House Architecture

Author. Sokolova, Maria Vasilievna - Ph. D., associate professor. Lomonosov Moscow State University, Leninskie Gory, 1, 119991 Moscow, Russian Federation. mar641079992007@yandex.ru

Abstract. The last years of Queen Victoria's reign saw a marked change in the country's economic and public life. If the preceding decades, known as the High Victorian age, saw the peak of the growth of the empire, the 1880s was the time of crisis and economic decline. That could not but impale the idea of a great national past which inspired certain architectural prototypes borrowed from what was seen as the golden age of the empire. The new social tendencies were reflected vividly in architecture including the work of $\mathrm{Ph}$. Webb. The article primarily concerns the country houses built by the architect. The British country house architecture saw some important changes in the Late Victorian age. Mainly, they concern the attitude toward national heritage. The High Victorian architects usually chose a distinct style or epoch in national architecture that they tried to imitate. In the Late Victorian era, architects often mix various styles and epochs in one project creating an image of an "Old English" house and Ph. Webb was the first one of them.

Keywords: Philip Webb, Victorian epoch, British architecture, English country house, national heritage, vernacular style

Название статьи. Национальное наследие и стиль в поздневикторианской архитектуре загородного дома 
Сведения об авторе. Соколова Мария Васильевна - кандидат искусствоведения, старший преподаватель. Московский государственный университет имени М. В. Ломоносова, Ленинские горы, д. 1, Москва, Российская Федерация, 119991. mar641079992007@yandex.ru

Аннотация. Последние годы царствования королевы Виктории ознаменованы резким изменением ситуации в экономической и общественной жизни страны. Если предшествующие десятилетия, так называемое высоковикторианское время, были своего рода пиком в развитии мощной империи, то начиная с 1880-х гг. экономическое процветание идёт на спад, страна переживает несколько кризисов. Всё это не могло не пошатнуть сложившегося к этому времени представления о великом национальном прошлом, находившего себе отражение в ориентации на определённые архитектурные прототипы, памятники тех эпох, которые виделись как своего рода золотой век империи. Новые общественные тенденции живо отразились в архитектуре, в частности в зданиях, построенных Ф. Уэббом.

В статье рассматриваются его загородные дома. В архитектуре загородного дома в поздневикторианское время происходят значительные изменения. Прежде всего они касаются отношения к национальному наследию. Если архитекторы высоковикторианского периода избирали определенный стиль или эпоху, которым они стремились подражать, то архитектор поздневикторианского времени зачастую смешивал различные стили и эпохи в одном здании, создавая образ «староанглийского» дома. Ф. Уэбб одним из первых среди викторианских архитекторов отказался от следования единому стилю в своих проектах загородных домов.

Ключевые слова: Филипп Уэбб, викторианская эпоха, британская архитектура, национальное наследие, «сельский» стиль 